\title{
Religiosity Performance of BMT Leaders and Its Implications to Sukuk Preference
}

\author{
${ }^{1}$ IMA AMALIAH, ${ }^{2}$ TASYA ASPIRANTI, ${ }^{3}$ WESTI RIANI \\ ${ }^{1,2,3}$ Universitas Islam Bandung, West Java, Indonesia \\ Correspondence author: amalia.razi@gmail.com
}

\begin{abstract}
BMT has a strategic role in the marketing of State Sukuk since this institution is a party that has capital constraints for the development of its business activities. This study aimed to analyze the performance of BMT leaders' religiosity value and their implications for the preferences of State Sukuk. This study uses a quantitative descriptive approach with field survey methods. 22 BMT leaders become the research sample with the institutions scattered in regencies and cities in West Java. The measurement of the performance variable of religiosity and preference uses a Likert scale 5 . The results show that the religiosity performance of BMT leaders in West Java is categorized as good. However, a good understanding of religious values does not instantly boost BMT leaders' preference for State Sukuk. Inadequate information on the operationalization mechanism of State Sukuk is one of the reasons for the low preference of BMT leaders for state Sukuk
\end{abstract}

Keywords: religiosity, state sukuk, bmt

\section{Introduction}

State Sukuk has an important role in the Indonesian economy since it can be an alternative source of funding for development which currently has been fulfilled by foreign debts. From the published data of the Indonesian Ministry of Finance (2019), the proportion of Indonesia's 2017 State Budget deficit was recorded at $2.57 \%$ of the APBN and continued to decline to $2.12 \%$ in 2018 and $1.84 \%$ in 2019 . This reduction in the proportion of the APBN deficit was in line with a decrease in the proportion of financing from foreign debt, wherein in 2017, the proportion of foreign debt from the APBN was recorded at $9.1 \%$. In 2018 it increased significantly to $29.5 \%$ and fell again to $9.7 \%$ in 2019 . The decrease in Indonesia's dependence on foreign debt financing is in line with the increasing proportion of State Sukuk in APBN financing, where the amount has reached $30 \%$. Since its issuance in 2013 to 2018, the total allocation of State Sukuk for infrastructure financing has reached 62.4 trillion rupiahs, namely for constructing various road and bridge infrastructure, construction of railways, and water resources construction projects such as dams, irrigation, supply and management of groundwater (Ministry of Finance, 2019).

The presence of State Sukuk has a very strategic role in the economy as seen from its role as a source of government funding free from exchange rate fluctuations and in line with Islamic values (Muhammad, Permana \& Nugraheni, 2019). State Sukuk can be an alternative source of funding for Islamic microfinance institutions (BMT or Baitul Maal wat Tamwil) that are not risky and do not involve usury. Classically, all BMT has the same problem that is limited capital, so that it isn't easy to win the competition. So far, most BMTs have allocated their assets in the form of deposits at conventional commercial banks, even though conventional commercial banks operate using interest rates. Thus, there is a difference in vision between BMT and Conventional Commercial Banks. BMT should develop its assets in a portfolio that is free of interest or usury.

Although the State Sukuk is a risk-free instrument and in line with Islamic values, the presence of State Sukuk amid Islamic microfinance institutions (BMT) is still not evenly recognized. From the interviews

Received: 2020-03-28, Revised: 2020-05-05, Accepted: 2020-12-30

Print ISSN: 0215-8175; Online ISSN: 2303-2499. DOI: hthttps://doi.org/10.29313/mimbar.v36i2.6145

Accredited Sinta 2 based on the decree No.10/E/KPT/2019 until 2024. Indexed by DOAJ, Sinta, Garuda, Crossreff, Dimensions 
with BMT actors, BMT leaders are still very unfamiliar with the types of State Sukuk products. BMTs are often associated with banks, which are considered the agents for selling state Sukuk. This means that banking has not been optimally used as an intermediary for information on State Sukuk to microfinance institutions. Observations and discussions with BMT leaders revealed that they had never heard of State Sukuk. Knowledge of State Sukuk is still very limited. The BMT leader admitted that he did not know how to have a State Sukuk, where he should go to get a State Sukuk, has no information of the profit-sharing system, and how to sell the State Sukuk if he needs new funds quickly. The limited knowledge of BMT leaders causes poor perceptions. BMT leaders consider the state Sukuk to be the same as other securities, which still involve usury, speculation, and gharar (Nafsiah, 2014). The effect is that some BMT leaders have not invested in sharia securities yet, including in State Sukuk.

BMT is a sharia non-bank microfinance institution operated under sharia principles, fostering micro and small business businesses in elevating the degree and dignity and defending the interests of the poor. BMT can reduce regional inequality, especially in the economic sector (Hidayat, 2018). Conceptually, BMT has two functions: a social function as a social fund manager and an economic development function to improve small and medium enterprises (Zahra \& Wijayanti, 2019; Zulkifli, Hamzah \& Hamzah, 2016). BMT is a sharia financial institution that protects MSMEs from the interest and loan sharks (Fitriani \& Darma (2016).

The purpose of establishing BMTs is to facilitate community groups that are not reached by the banking sector and the Sharia Rural Bank. The duties of BMTs are often outweighed by high competition among financial institutions. Limited capital often makes BMT products more expensive than other financial institutions. Therefore, it is necessary to find low-cost alternative funding with less risk, one of which is Sukuk. It is suspected that the lack of knowledge of BMT leaders about the state Sukuk impacts the leadership's low preference towards the State Sukuk.

A person's preference to consume a product is influenced by a person's personality factors so that preference is defined as a buyer's taste as measured by the extent to which a person's perception of the offer regarding its uses and benefits (Guleria, 2016). The buyer normally uses their preferences when comparing alternatives and options. Preferences based on scientific evaluation are always rational preferences. Real-life product marketing prioritizes several factors' rationalization, especially in an environment that is constantly changing and has limited resources (Ramkumar \& Rajapandian, 2016).

Public preference for State Sukuk is not only because investment in State Sukuk will provide many economic benefits at maturity, but also because State Sukuk are Islamic bonds that are free from usury, gharar, and maysir activities. There is a guarantee of State assets (back assets) as one of the government's prerequisites for issuing Islamic securities (Amaliah et al., 2020). Thus, the factor that will make someone choose Sukuk Negara is not only due to its economic value but also the level of confidence and faith that the product they choose not only benefits in the world but also in the hereafter. In other words, the person concerned has a good level of religiosity.

Religiosity means being obedient to religion, so it can be said that religiosity is one's obedience to the commandments of one's religion. Another definition of religiosity is the knowledge, beliefs, the practice of worship and its rules, and the extent to which respect for the religion they profess (Zahrah, Hamid, Rani, \& Kamil, 2016; Iddagoda \& Opatha, 2017). In an individual's view, religiosity is determining how strong an individual adheres to religion, experiencing daily religious experiences, experiencing the meaning of life in religion, expressing religion as a value, believing in his religion, forgiving, practicing religion, or worshipping (Warsinangin \& Kusumawardhani, 2018). Religiosity is about belief and the implementation of the religious values that it believes in (Purnamasari, Amaliah, 2015). From these definitions, religiosity concerns how an individual understands, internalizes, and integrates religious norms into himself and becomes part of his personality. Therefore, religiosity includes a condition that encourages someone to think, behave, and act according to their beliefs.

Religiosity is seen from five dimensions (Purnamasari and Amaliah (2015): ideological dimension, ritualistic dimension, experience dimension, intellectual dimension, and 
practice dimension. An ideological dimension is a dimension that relates to the level of one's belief in religious values, especially fundamental teachings/values. or dogmatic; ritualistic dimension is the dimension related to the level of one's compliance in carrying out ritual activities as ordered by his religion; experiential dimension is closely related to the level of one's religious feelings and experiences; intellectual dimension is related to the level of one's knowledge and understanding of religious values, especially about basic teachings or values that can be found in scripture; practice dimension is closely related to the level of individual behavior that is motivated by religion.

According to Yusuf and Khan (2015), religious belief is belief in myth, supernatural or spiritual reality from a religious aspect. Religious beliefs are derived from religious ideas related to Allah's existence, characteristics and worship, God's intervention in the universality and human life, or deontological explanations of religious values and practices that focus on spiritual or group leaders. Religious activity is close to religiosity, not only in the form of the ritual itself but also in work activities. Religiosity can predict human behavior in the workplace (Dewi et al., 2020).

In Islam, it is important to invest in additional physical assets and activities in the real sector (Huda et al., 2018). Investment in the macroeconomy is differentiated into autonomous investment and induced investment. Autonomous investment is an investment that is not influenced by national income. This investment may include physical investment and various government securities based on both interest rates and sharia (one of which is state Sukuk). According to Law No. 19 of 2008, Sukuk Negara are government securities issued based on sharia principles, as evidence of the share of investment in SBSN assets in rupiah and foreign currencies. State Sukuk as a state budget financing instrument in the form of securities. The basis for the issuance of State Sukuk is state assets in the form of state-owned goods or APBN projects (Ministry of Finance, 2015). State Sukuk are free from the risk of default considering that the payment of compensation and nominal value is guaranteed by law. The yield from State Sukuk can be fixed and floating, depending on the Sukuk structure it chooses. State Sukuk can be issued on the domestic and international primary market and in rupiah and foreign currency (Ministry of Finance, 2015).
Based on the description above, it can be seen that previous research regarding preferences for various physical and nonphysical products, the concept of religiosity, have implications for behavior, especially in the workplace. Research on how preference for a Sukuk investment product is influenced by religiosity has not been carried out. Its because Sukuk investment is still not popular as a form of a bond investment. Specifically, this research aims to identify and analyze: first, the religious performance of BMT leaders in West Java; Second, the implications of religious performance of BMT leaders to the preference for state Sukuk. The composition of the following writing is the research methodology, analysis, discussion, and conclusions and policy implications.

\section{Research Methodology}

The method used in this research is descriptive quantitative with field survey methods. The research team distributed questionnaires to BMT leaders, conducted interviews for data validation, and extracted several pieces of information needed to analyze the result. In this study, respondents were leaders of Baitul Maal Wattamwil (BMT) who were scattered in regencies and cities in West Java. From an online data search, the number of BMT in West Java is 40 BMT. However, at the time of the survey in districts and cities in West Java, only 22 BMTs were successfully traced in Bandung City, Bandung Regency, Cimahi City, West Bandung Regency, Cirebon Regency/City, Tasikmalaya City, Garut Regency, Cianjur Regency, and Sukabumi City. BMT in the Kuningan area are mostly branches of the Cirebon region BMT. Therefore, the research team only conducted a survey of BMT in Cirebon Regency/City. See in figure 1.

The method of withdrawing respondents is done by random snowball sampling because the data availability is not the same as the field data. Many BMTs are still registered online, but the fact is that many BMTs have moved places and even have closed their businesses. Therefore, the research team optimized the search for respondents using previous informants to obtain real BMT data in the field.

The research team used descriptive statistical methods to answer the problem formulation, namely by calculating the proportion of responses and presenting them in Tables and graphs. 


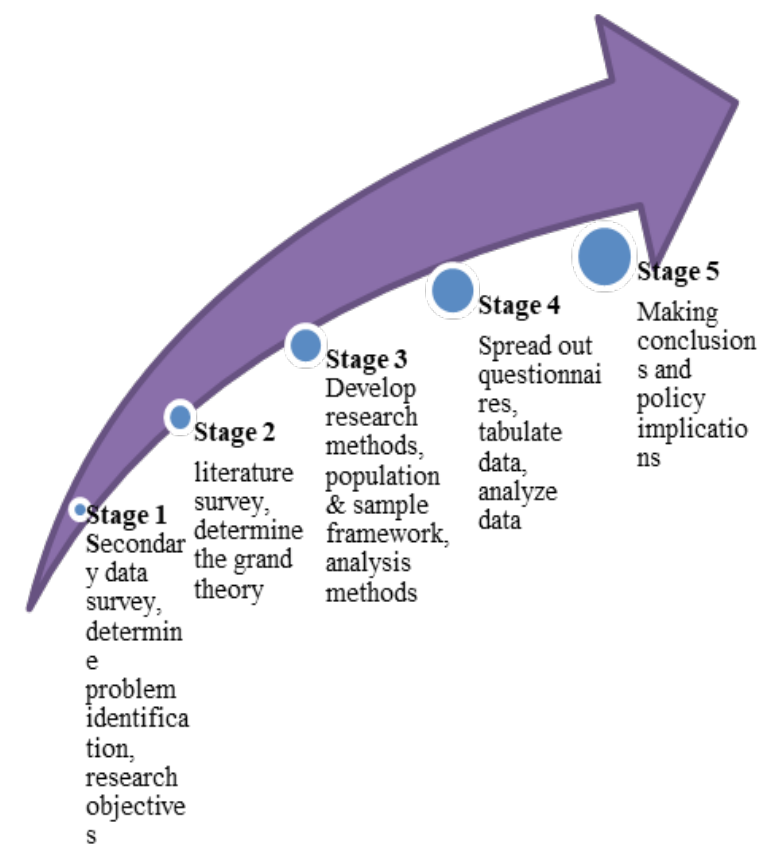

Figure 1. Research Procedure

5-point Likert scale was used to measure the performance variables of religiosity and preference. The author conducted five classifications of religiosity and preference's performance variables: very low, low, sufficient, good, and very good. The classification is made based on the tabulation of the frequency distribution of respondents 'answers with the following stages, namely: (1) Determining the maximum and minimum score for respondents' answers, where the maximum score is the maximum number multiplied by the number of respondents times the number of questions. While the minimum score is the minimum number times the number of respondents times the number of questions; (2) Determine the range of the classification class, namely the range equal to maximum x - minimum x; (3) Determine the number of classifications of 5 classes consisting of very low, low, sufficient, good and very good); (4) Determine the interval class, namely the range divided by the number of qualifications; (5) Distribute data into qualifying classes.

\section{Results and Discussion}

\section{Religiosity Performance of BMT Lead- ers in West Java}

To be able to capture the religious performance of BMT leaders, namely BMT leaders spread across West Java, researchers developed a dimension of religiosity from five dimensions (Purnamasari and Amaliah, 2015), namely: ideological dimensions, ritualistic dimensions, experiential dimensions, intellectual dimensions, and practical dimensions. The ideological dimension is derived into indicators of (a) Beliefs of BMT leaders regarding their religious values; (b) The belief of BMT leaders about the teachings of their holy books; (c) Understanding BMT leadership about the Prophet's teachings' hadith.

The ritualistic dimension is revealed in two major indicators: (a) The compliance of BMT leaders in carrying out obligatory worship, which consists of 4 sub-indicators); (b) Compliance with BMT leadership in carrying out Sunnah worship, which consists of 12 sub-indicators. The experience dimension is developed into an indicator, namely the alignment of BMT leaders' behavior with Islamic values.

The intellectual dimension is derived into three indicators, namely: (1) Understanding of BMT leaders about the teachings of tauhid; (2) Understanding BMT leadership about Islamic law; (3) Understanding BMT leaders about religious behavior. The practical dimension is developed into an indicator, namely the level of consistency of BMT leaders in carrying out social worship, namely: (a) Behavior towards parents, spouses, children and their relatives; (b) Behavior towards neighbors or the surrounding community; (c) Behavior towards peers; (d) Behavior towards superiors; (e) Behavior towards its staff.

From the results of data processing related to the understanding of BMT leaders in West Java from the ideological dimension (belief), it is seen that $98.33 \%$ believe in their religious values, believe in the teachings of the Koran (Qur'an), and understand the hadiths of the Prophet. It means that BMT leaders have very good faith in the values of their religious teachings in terms of belief. This good belief in religious values will impact the performance of BMT leaders, as findings fromWarsinangin \& Kusumawardhani (2018). Belief in religious values will influence decisions (Bukhari, 2019), including decisions in investing, namely investments by sharia values. Ramlee et al. (2016) found that religiosity and work attitudes significantly affect organizational behavior. Furthermore, Yeniaras \& Akarsu (2017) found that the ideological dimension has a non-linear correlation with life satisfaction. Religiosity can strengthen the relationship between spiritual 
intelligence and employee performance (Noegroho \& Wulansari, 2020). We can see in the graph 1

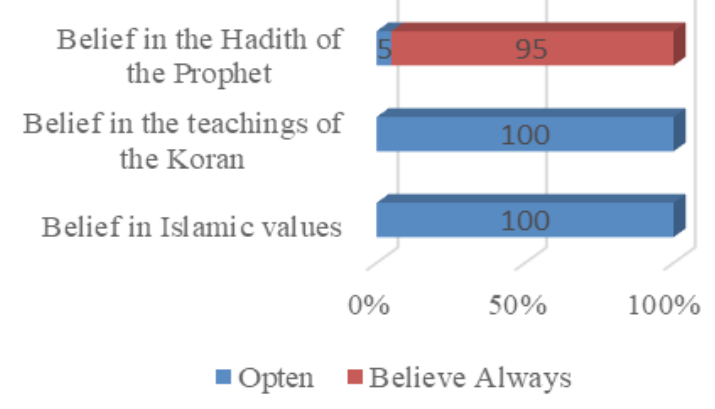

Graph 1 the Level of BMT Leadership from the Ideological Dimension

The ritualistic dimension developed in two major indicators, namely adherence to compulsory worship and sunnah worship. From the implementation of compulsory worship, generally, BMT leaders in West Java admit to always performing compulsory prayers, compulsory fasting (Ramadan fasting), paying zakat (fitrah), and performing the haj pilgrimage. Some BMT leaders admit to paying zakat mal (wealth) every month. That is, the office is immediately deducted by 2.5 percent. Regarding the Hajj, only $5 \%$ have performed the Hajj pilgrimage, and the rest admit that they have planned to carry out the Hajj. BMT leaders' compliance in carrying out worship must prove that BMT leaders have good religious values that will have implications for the balance of their body and soul, for the immunity and quality of life, and leaders will be able to manage the BMT business even better.

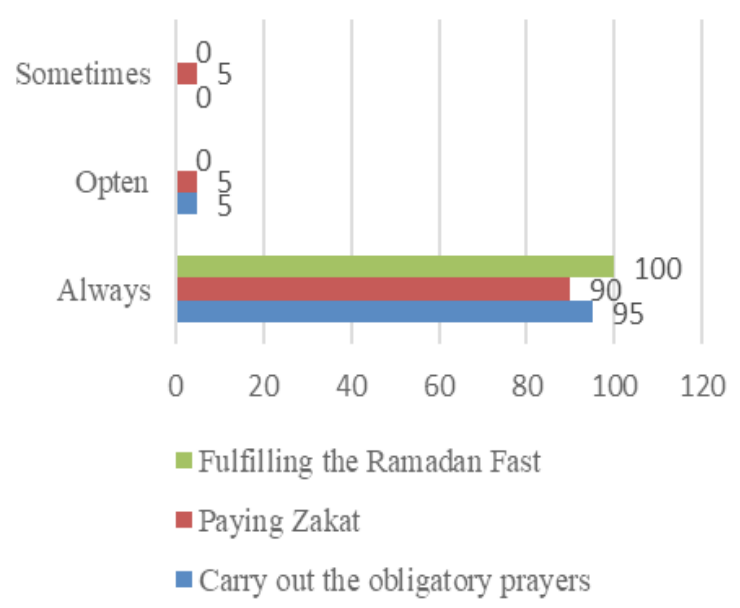

Graph 2 The Level of Religiosity from the Ritualistic Dimensions in Carrying out Compulsory Worship
With an alternative investment based on Islam, it is hoped that BMTs will not be built with investment returns that still involve interest (deposits at commercial banks) but begin to be directed towards sharia-based portfolio diversification. We can see in the graph 2.

There are many kinds of opinions for sunnah worship, such as Dhuha Prayers, Tahajud Prayers, Tahiyatul Mosque Prayers, Monday-Thursday Fasting, Daus (David) Fasting. For the Rawatib prayer (before and after the obligatory prayer), 50 percent of BMT leaders admit that they often practice sunnah, and $23 \%$ have never done it. For the Tahajud prayer, 45 percent admitted that they sometimes do it when they have problems in their life. For the Sunnah Fasting of Monday and Thursday and Daud Fasting, the BMT leadership admitted that they rarely do it (just sometimes). While participating in the Ta'lim Assembly and paying Infaq-Shadaqah, BMT leaders admit they often do it.

Judging from the obedience of carrying out the Sunnah worship, it seems that the BMT leadership is still in the good category. A good understanding of Islamic values will be well implemented in ethics (behavior) (Amaliah, Julia, \& Riani, 2013). Bukhari (2019) found people who have a high level of religiosity tend to follow Islamic principles in every decision. Thus, ritual activities are not only carried out because they have problems but also because of a calling. We can see in the graph 3 .

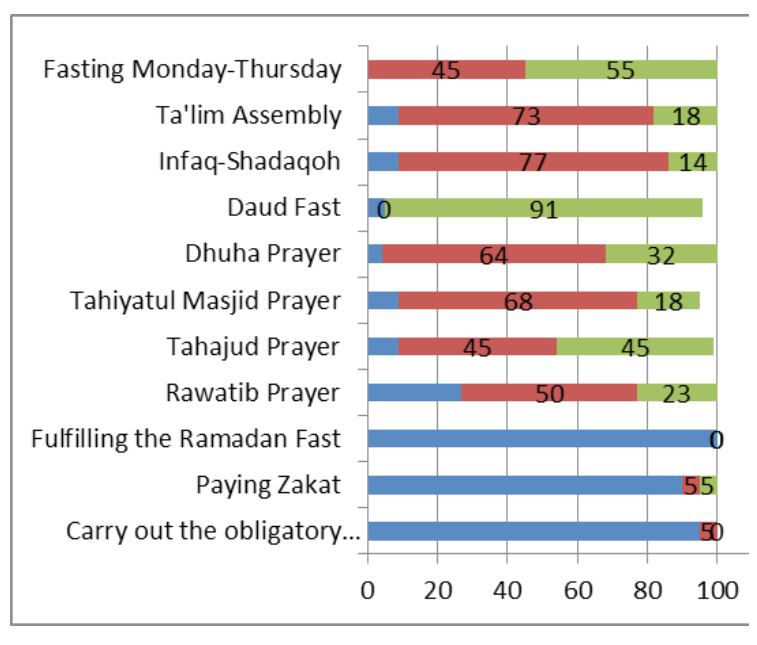

Graph 3 Religiosity Level of BMT Leaders from Ritualistic Dimensions Carry out Sunnah Worship

For the experience dimension, which is seen from the alignment of BMT leadership behavior with Islamic values identified $68 \%$ of 
leaders claimed to be in harmony, and $18 \%$ claimed to be very aligned. This dimension can be quite a complicated one considering that many people know faith, sharia, and morality. Still, it is often not in accordance with the guidance of religious values at the level of implementation. As for BMT's leader, the alignment of behavior with Islamic values can be seen from the punctuality of carrying out compulsory worship and sunnah worship, investing in products free from the elements of usury, gharar, and maiysir, and other aspects of muamalah. From the results of the interview, it was revealed that BMT leaders still use economic considerations in deciding investments. This means that the concept of profit and loss is still an important consideration in making investment decisions. It can be seen from the allocation of BMT assets, which are still kept in conventional banks. Compliance and commitment to sharia should be the backbone of Islamic financial institutions (Nurhasanah, 2013). We can see in the graph 4

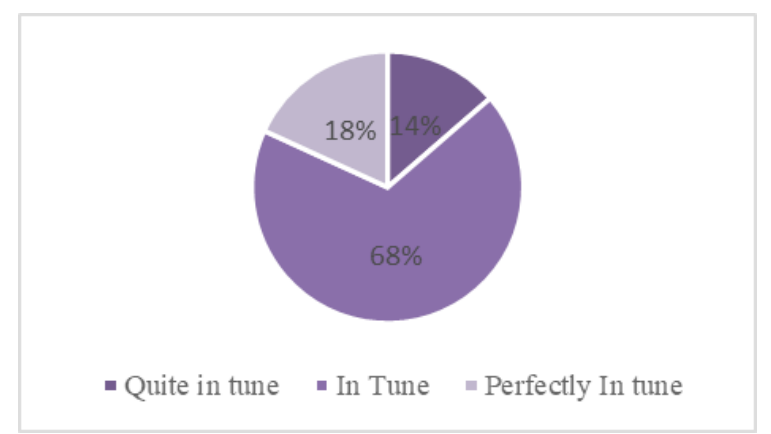

Graph 4 Religiosity level of BMT Leaders from Experience Dimensions

Viewed from the intellectual dimension, BMT leaders generally have a good understanding of the Oneness of God and Islamic laws, especially concerning aspects of muamalah and morality (good and bad behavior or right and wrong). These three aspects are inseparable parts because if the BMT leader has good faith in God, he will try to understand his religious laws and try to behave according to the teachings of his religion. In general, BMT leaders have a good religious background since BMT organizations are formed by people who have the same vision and mission, namely from the same recitation place. Studies on monotheism, muamalah, and morality are usually systematic studies discussed in the ta'lim assembly. It is in line with the findings of Soma et al. (2017), where both managers and the public have not used the intellectual dimension in understanding Islamic banks.

The concept of unity in Islam is an important part of developing a business where worship and business are not separate activities. We can see in the graph 5

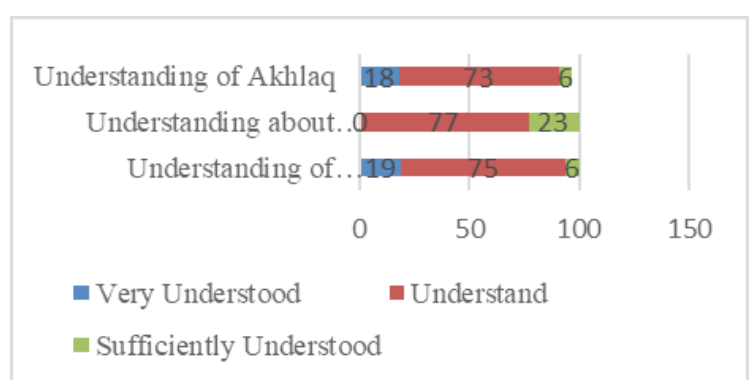

Graph 5 Religiosity Level of BMT Leaders from Intellectual Dimension

The practical dimension is developed by deriving into several social relations indicators carried out by BMT leaders with parents, spouses, and children; relationships with neighbors and friends; relationships with superiors, colleagues, and staff. The results of data processing revealed that BMT leaders have good relationships with parents, spouses, children, and close relatives.Likewise, relationships with neighbors, peers, and staff. BMT leaders admit that peers and staff are an important part of BMT development so that building good communication with them is necessary. According to the Head of BMT, technical errors in BMT operational activities must be communicated properly so that the staff understands the company's intentions. We can see in the graph 6 .

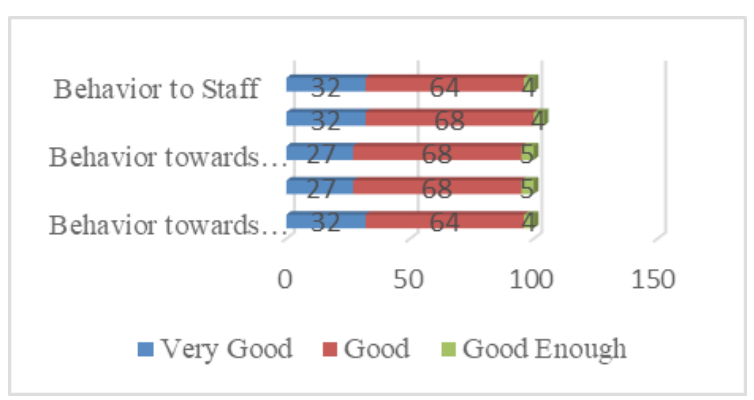

Graph 6 Level of Religiosity from the Practical Dimension

From the explanation above, it can be seen that the religious performance of BMT Leaders in West Java, viewed from the dimensions of ideology, ritualistic, experience, intellectual and practical, is categorized as good. This is the basis for BMT development because various empirical findings show a positive relationship between religiosity with hard work orientation and 
work attitudes. Leaders make hard work as a form of self-sacrifice for their God. Besides, the value of religiosity can reduce the tendency of employees to leave the company (Olowookere,Oguntuashe \& Adekeye, 2016; Hassan, Mohammad, Rozilah, \& Ali, 2015; Malik, 2020), because religiosity value has created job satisfaction (Malik, 2020).

\section{Implications of Religiosity Value on Preference for State Sukuk}

The previous discussion shows that the leadership of BMT in West Java has a good performance of religiosity. This is indicated by the weighted average of the five dimensions in the good region. However, a good understanding of Islamic values is not necessarily a part of determining factor for society in choosing sharia products (Dawami, 2020; Christanti, et al., 2018)

The preference of BMT leaders in West Java is seen from the dimensions of state Sukuk's suitability with Islamic values, namely $45 \%$ stated that they are following Islamic values and $36.4 \%$ sufficiently follow Islamic values. The ratio of responses between those that are suitable and those that are moderately suitable is almost equal. It proves that the BMT leadership still does not fully understand the State Sukuk. It was revealed during an interview with BMT leaders, in which a group that did not understand claimed to have heard about the state Sukuk but did not understand. This group admits that they only know about state bonds, which are interest rate based. The lack of knowledge and information about the State Sukuk led some BMT leaders to their conclusions without finding further information about Sukuk. We can see in the graph 7.

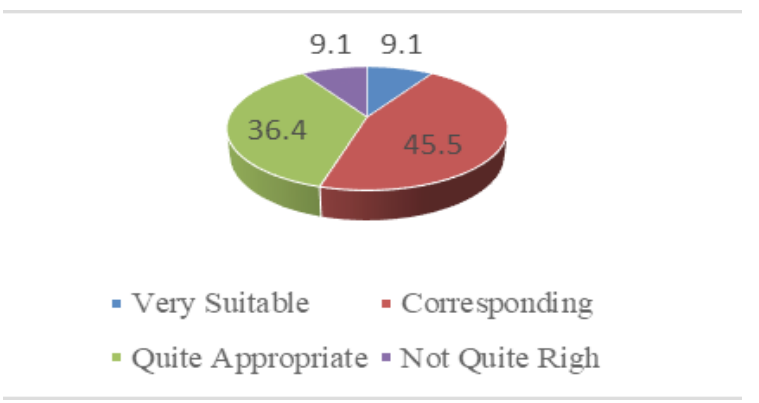

Graph 7 Compatibility of State Sukuk with Islamic Values

From the State Sukuk's risk aspect, most BMT leaders admit that the risk of sovereign Sukuk is low. As many as 22.2 percent of BMT leaders admitted that the risk of sovereign
Sukuk was high. Understanding the high risk of sovereign Sukuk is based on BMT leaders' common knowledge about sovereign Sukuk. According to a group of respondents who agree that state Sukuk has low risk is based on state Sukuk's working mechanism, which does not involve interest rates, guarantees state assets, and has clear legal umbrella. Meanwhile, in conventional bonds, investors do not know the exact collateral assets of the bond issuance. Therefore, BMT leaders choose to invest in State Sukuk because the risk they have to bear is very small, which is guaranteed by the government in its issuance. We can see in the graph 8.

$$
\begin{aligned}
& \text { - Very Low } \quad \text { "Low } \\
& \text { - High } \\
& \begin{array}{c}
\text { Graph } 8 \text { Preference for Sukuk from the Risk } \\
\text { Dimension }
\end{array}
\end{aligned}
$$

\section{Graph 8 Preference for Sukuk from the Risk}

The third dimension that determines the preferences of BMT leaders in choosing State Sukuk is investment satisfaction. Most BMT leaders admitted that they were quite satisfied choosing to invest in State Sukuk. Meanwhile, those who claim to be satisfied have only reached 18-23 percent. There are still BMT leaders who do not provide answers regarding alternative investments in state Sukuk. After conducting further interviews, it was revealed that the reason for not investing in state Sukuk was because they did not understand the mechanism for conducting state Sukuk transactions. After being explained, it was seen that there was an intention from the BMT leadership for the state Sukuk. We can see in the graph 9.

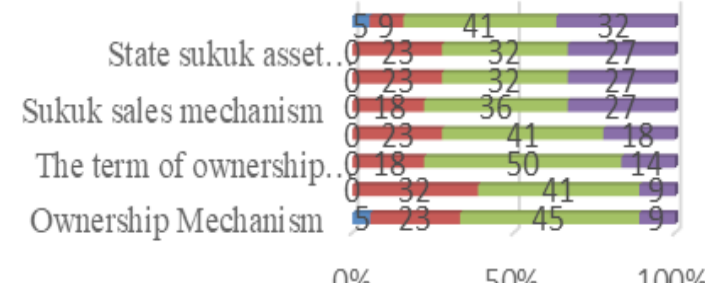

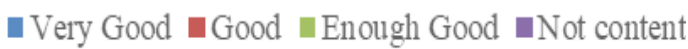

Graph 9 the level of preference for the leadership of the Satisfaction of State Sukuk Ownership 

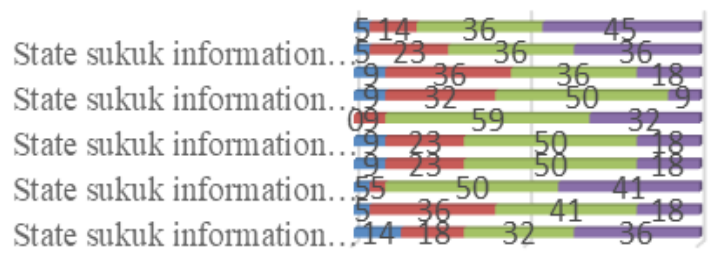

0

50

100

$\begin{array}{ll}\square \text { Adequate } & \square \text { Sufficiently } \\ \text { Inadequate } & \square \text { Do not Answer }\end{array}$

Graph 10 Preference Levels of BMT Leaders on State Sukuk Information Sources

Another reason that BMT leaders do not like the state Sukuk because there is insufficient information about Sukuk. So far, BMT leaders get information about state Sukuk only from family, friends, and neighbors. Only a few BMT leaders have ever received information from state Sukuk selling agents, financial institutions, and state Sukuk owners. Inadequate information on state Sukuk has been one reason for BMT leaders' low preference in investing in the Sukuk portfolio. Thus, although the understanding of religious values from the BMT leadership is very good, yet inadequate information about the state Sukuk affects the low preference of the BMT leadership towards the state Sukuk. We can see in the graph 10 .

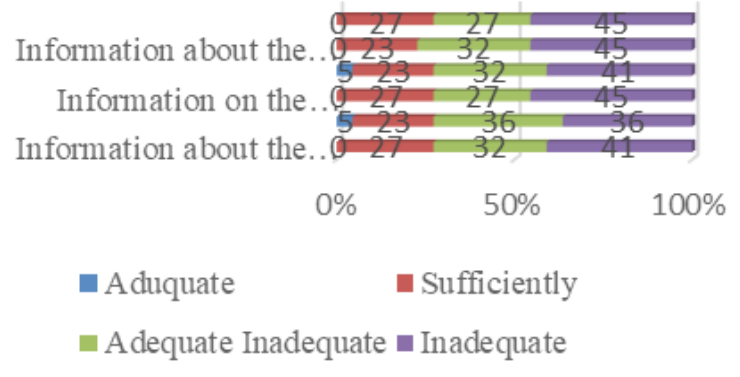

Graph 11 Preference of Level BMT Leaders to State Sukuk from the Product Information Dimension

Inadequate sources of information on State Sukuk results in insufficient information on how the Sukuk are operationalized. Most BMT leaders in West Java feel that they do not have sufficiently good information about state Sukuk's liquidity level, the mechanism for ownership of state Sukuk, reselling the State Sukuk, and the risks and returns of State Sukuk. From the two information indicators, it can be seen that the information held by BMT leaders regarding the operation of state Sukuk is very inadequate. The effect is that the perception formed about the State Sukuk has not been optimal and impacts the absence of BMT leaders to choose the state Sukuk as one of their alternative portfolios.

\section{Conclusions}

The five indicators developed identified that BMT leaders in West Java had good religiosity performance. This is identified from the five dimensions' weighted value, namely ideological dimension, ritualistic dimension, experiential dimension, intellectual dimension, and practice dimensions in the positive region, which is very suitable and appropriate. From the ritualistic dimension, doing Sunnah worship is also still in a good category.

The good performance of religiosity does not have implications for the leadership's high preference in investing in sharia bonds (including state Sukuk). Lack of information and education from the government regarding state Sukuk is one of the causes why most BMT leaders in West Java don't choose to invest in state Sukuk. Even though the banking sector, as one of the state Sukuk sales agents, has not been able to bridge the state Sukuk's lack of information. Besides, even though the level of religiosity of BMT leaders was already in a good category, it has not impacted the decision-making in BMT asset allocation. BMT leaders still place their funds in deposits at conventional commercial banks.

Therefore, the suggestion for future research is to conduct a more comprehensive and quantitative study of the magnitude of the influence of religiosity values on leadership performance and its implications for state Sukuk investment decisions.

\section{References}

Amaliah, I, Tasya Aspiranti, Ceacile Putri Ciptadi, Putri Widia. (2020). Sukuk: A Macroeconomic Variable Approach. Jakarta: Rajagrafindo

Amaliah, I., Julia, A., \& Riani, W. (2013). The Influence of Islamic Values on Work Performance. MIMBAR: Journal of Social Affairs and Development, 29 (2), 165-174.

Bukhari, SFH, Woodside, FM, Hassan, R., Shaikh, AL, Hussain, S., \& Mazhar, W. (2019). Is religiosity an important consideration in Muslim consumer behavior. Journal of Islamic Marketing.

Christanti, EH, Wulandari, D., Narmaditya, BS, 
\& Utomo, SH (2018). Factors Influencing Customers In Using Islamic Banking Service. UNEJ e-Proceeding, 260-268.

Dawami, Q. (2020) Factors Influencing the Preference of Customers Towards Islamic Banking: Evidence from Malaysia. Journal of Islamic Economic Laws, 3 (1), 48-67.

Dewi, SS, Madjid, A., \& Fauzan, A. (2020). The Role of Religiosity in Work-Life Balance. Budapest International Research and Critics Institute (BIRCI-Journal): Humanities and Social Sciences, 3 (3), 2363-2374. https://doi.org/10.33258/ birci.v3i3.1192

Fitriani, P., \& Darma, ES (2016). The Role of Baitul Maal Wat Tamwil Financing on Business Development and Increasing the Welfare of Its Members from the Micro Sector of Traditional Market Traders. Journal of Accounting and Investment, 17 (2).

Guleria, D. (2016). a Study of Consumer Preference for Online Shopping. International Journal of Management Research \& Review, April, 1-184

Hassan, N., Mohammad, A., Mohd, F., Rozilah, A., \& Ali, S. (2015). Religiosity perceptions and employee turnover intention in Malaysia. International Journal of Social Science and Humanity, 5 (1), 120-125.

Hidayat, S. (2018). Public Perception of Baitul Maal Wat Tamwil (BMT) in Community Economic Empowerment. al-Uqud: Journal of Islamic Economics, 2 (2), 198-212.

Huda, Nurul, Handi Rsza Idris, Mustafa Edwin Nasution, Ranti Wiliasih. (2018). Islamic Macroeconomics: A Theoretical Approach. First Edition. Jakarta: Golden

Iddagoda, YA, \& Opatha, HHDNP (2017). Religiosity: Towards a conceptualization and an operationalization.

Olowookere, EI, Oguntuashe, KA, \& Adekeye, OA (2016). Relationship between religiosity and citizenship behavior in organizations: Empirical evidence from selected organizations in Lagos State. Mediterranean Journal of Social Sciences, 7 (4), 475.

Warsinangin, J., \& Kusumawardhani, A. (2018). Islamic relationship value, adaptive selling, and, relationship quality effect to salesforce performance. Journal of Business and Retail Management Research, 12 (4).

Purnamasari, P., \& Amaliah, I. (2015). Fraud prevention: relevance to religiosity and spirituality in the workplace. ProcediaSocial and Behavioral Sciences, 211, 827-835.
Ministry of Finance (2019). Indonesian State Budget. Jakarta: Ministry of Finance.

Ministry of Finance (2015). State Sukuk: Sharia-based Financial Instruments. Central Jakarta: Directorate of Sharia Financing-DJPR Ministry of Finance

Noegroho, AD, \& Wulansari, NA (2020). Religiosity as a Moderation of the Effect of Intellectual and Spiritual Quotient on Employee Performance. Management Analysis Journal, 9 (2), 113-121.

Nafsiah, N. (2014). Analysis of the Development of State Sukuk and Transaction Mechanisms in the Capital Market in Indonesia. AL-INFAQ, 5 (1), 15-26.

Nurhasanah, N. (2013). Islamic supervision in the operations of Islamic financial institutions. MIMBAR: Journal of Social Affairs and Development, 29 (1), 11-18.

Malik, N. (2020). The Influence of Turnover Factors Toward Employees' Intention to Stay: A Case Study in Indonesian Islamic Universities. Journal of Industrial Engineering, 21 (1), 80-91.

Muhammad, R., Permana, EN, \& Nugraheni, P. (2019). Retail Sukuk Demand Level: Analysis of Internal and External Factors. Media Research Accounting, Auditing \& Information, 19 (2), 249-264.

Ramkumar, N., \& Rajapandian, R. (2016). * Assistant Professor, Department of Management Studies, Paavai Engineering College, Pachal, Namakkal ** II MBA Student, Department of Management Studies, Paavai Engineering College, Pachal, Namakkal. International Journal of Innovative Research in Management Studies (IJIRMS), 1 (6), 43-53. http://ijirms.com/ downloads/211120162016010603.pdf

Ramlee, N., Osman, A., Salahudin, SN, Yeng, SK, Ling, SC, \& Safizal, M. (2016). The influence of religiosity, stress and job attitude towards organizational behavior: evidence from public universities in Malaysia. Procedia Economics and Finance, 35, 563-573.

Soma, AM, Primiana, I., Wiryono, SK, \& Febrian, E. (2017). Religiosity and Islamic banking product decision: survey on employees of PT Telekomunikasi Indonesia. Ethics, 16 (1), 194867.

Yeniaras, V., \& Akarsu, TN (2017). Religiosity and life satisfaction: A multi-dimensional approach. Journal of Happiness Studies, 18 (6), 1815-1840.

Yusuf, CF (2015). Misinterpretation of Qur'anic Verses on the "Islamic" Jihad. Heritage of Nusantara: International Journal of 
Religious Literature and Heritage, 3 (1), 129-154.

Zahra, MH, \& Wijayanti, P. (2019). Antecedent financial performance of Baitul Mal wat Tamwil (BMT): Study in BMT Binama Semarang. Journal of Islamic Accounting and Finance Research, 1 (1), 47. https:// doi.org/10.21580/jiafr.2019.1.1.3729

Zahrah, N., Abdul Hamid, SN, Abdul Rani, SH, \& Mustafa Kamil, BA (2016). Enhancing job performance through Islamic religiosity and Islamic work ethics. International Review of Management and Marketing, 6 (S7), 195-198

Zulkifli, Z., Hamzah, Z., \& Hamzah, H. (2016). Baitul Maal Wat Tamwil (BMT) Problem Analysis through the Analytical Network Process (ANP) Approach. Al-Hikmah: Journal of Religion and Science, 13 (1), 18-29. 